\title{
7 Summary and Outlook
}

The present study set out to achieve two main objectives: i) to give a comprehensive description of Sumerian constructions involving a copula, and ii) to reconstruct the system of focus marking in Sumerian.

The first two chapters functioned to provide background to the main parts of the work, making it accessible for readers not familiar with the grammar of Sumerian and with the writing system used to record it. Chapter 1 gave a short introduction to the grammar of Sumerian, describing its nominal and verbal template, and its case system. It also provided a characterization of the text corpus used as linguistic evidence. Chapter 2 described the most important characteristics of Sumerian non-verbal predicates.

Chapter 3 gave a typology of Sumerian copular clauses. It started with an overview of the linguistic literature on copular clauses, introducing the semantic types of copular clauses that served as the basis of the subsequent description of Sumerian copular clauses. The main part of the chapter described the Sumerian copular clauses in terms of their semantic type and information structure. It established four basic types of copular clauses: type (A) clauses, in which the subject of the clause functions as a topic; type (B) clauses, in which the topic or one of the topics of the clause is a constituent other than the subject, most frequently the left-dislocated possessor of the predicate complement or the subject; type (C) clauses, which have no topic; and type (D) clauses, in which the order of the subject and the predicate complement is inverted. It was established that type (D) clauses were specificational copular clauses and their subjects functioned as identificational foci. A fifth type of construction, type (E) was also recognized: this type consists of biclausal constructions involving a type (D) and a type (A) copular clause, used to express exhaustive identification, corresponding functionally to English it-clefts. On the basis of this typology, it was concluded that Sumerian copular clauses had two particular structural positions to accommodate constituents functioning as topics and indentificational foci, respectively. The topic position was situated in the left periphery of the clause, while foci occurred in a particular structural position immediately before the copula.

Chapters 4 and 5 discussed the copular biclausal constructions of Sumerian. These constructions consist of an initial copular clause followed as a rule by a clause with a finite, non-copular verb. The defining characteristic of copular biclausal constructions is that one of the participants of the initial copular clause and one of the participants of the other clause are coreferential; the shared participant may occur as an overt NP only in the initial copular clause, and be present only in the form of a pronominal affix on the verbal predicate in the second clause. Two main types of copular biclausal constructions were recognized: i) the attributive, in which the shared participant functions as the topic in the initial copular clause; and ii) the specificational, in which the shared participant functions as the identificational focus in the initial copular clause. 
Chapter 4 discussed the attributive copular biclausal constructions. The analysis of these constructions showed that they were the manifestation of a rare relativization strategy labeled as paratactic by Kuteva and Comrie (2005): their initial unit is a paratactic relative clause whose head noun occurs within a relative clause that is formally fully identical to a non-subordinate copular clause involving an enclitic copula. The chapter demonstrated furthermore that the initial copular clause of attributive copular biclausal constructions overlapped functionally not only with relative clauses, but also with appositional constructions. Type (A) copular clauses with an affixed pronominal subject in particular were found to function as substitute constructions for appositional constructions with a pronominal anchor, which were ungrammatical in Sumerian. In many of the attributive copular biclausal constructions, the copular clause was found to function as a reason or concessive clause. Chapter 4 concluded with a section on attributive copular biclausal constructions in which the enclitic copula grammaticalized into a standard marker of similative constructions.

The subject matter of Chapter 5 was the specificational copular biclausal construction, which functionally corresponds to a cleft construction in English. The first part of the chapter discussed the origin of the Sumerian construction, comparing its characteristics with those of English it-clefts. The main difference between the English and the Sumerian constructions is that the constituent corresponding to the relativelike constituent of the English it-cleft is a non-subordinate main clause in the Sumerian construction. It was argued that the Sumerian specificational copular biclausal construction developed on analogy with the construction labeled type (E) in Chapter 3, called a paratactic cleft in Chapter 5, and that the development was facilitated by the influence of the other important language spoken in the area, Semitic Akkadian, which had a construction similar in many ways to the Sumerian one.

The second part of Chapter 5 focused on the question as to whether the copula may be considered a "true" focus marker in these constructions. In particular, it examined the case-marking and the position of the focal constituent. The case-marking of the focal constituents suggested that the original copula underwent a semantic shift, and functioned no longer as the verbal copula of a copular clause in these constructions, but rather as a focus marker. This conclusion was also supported by the data on word order in specificational copular biclausal construction, as the evidence showed that the position of focal constituents followed by the copula was no longer restricted to sentence initial position.

Nevertheless, the copula functioning as focus marker retained its morphosyntactic properties as a verbal copula, as it showed agreement with the focal constituent, and in subordinate contexts it used its independent form. The Sumerian system was therefore found to correspond to what Heine and Reh (1984: 181) call a "weakly grammaticalized system" and represents an intermediate stage in the grammaticalization of a copula into a true focus particle.

The evidence collected and discussed in Chapters 3 and 5 also made it possible to reconstruct the Sumerian system of focus marking. Identificational focus could 
be marked by two grammatical devices in Sumerian. Initially, it was associated with a particular structural position. This syntactic focus marking was almost certainly accompanied by prosodic prominence on the focal constituent as well. The other strategy was different but ultimately was also based on the syntactic device: identificational focus could also be expressed with a biclausal construction, a kind of cleft construction, in which the first clause was a specificational copular clause. In this copular clause the subject occupied a position immediately before the copula instead of its more usual clause initial position and functioned as identificational focus material. The biclausal construction with the initial specificational copular clause was the morphosyntactic context in which the copula underwent a semantic shift, and came to be reinterpreted as the marker of identificational focus. The reinterpretation of the copula as a focus marker had the consequence that the original biclausal, cleft-like character of the construction was blurred, and the inherently syntactic focus marking evolved into a morphological one. As a kind of morphological reinforcement, the copula functioning as a focus marker was occasionally also attached to constituents whose focality was already marked by their position. When Sumerian as a vernacular left the scene at the beginning of the 2nd millennium, it had a mixed system in which both syntactic and morphological focus marking played a role.

The last chapter of the work, Chapter 6, investigated constructions in which the copula was attached to a subordinate clause. Two main types of these constructions were recognized, which differed only in their function but not in their structure. The first type typically occurs at the beginning of administrative or legal texts, and in these sentences all participants are expressed with an overt lexical NP. It was argued that these constructions functioned to introduce new entities, the main characters of the ensuing text, into the discourse, and/or to provide a background or setting to the events described in the ensuing or main part of the text by providing information on the state of affairs preceding the time of the main events described in the text. The second type of these constructions functioned to express polarity focus in Sumerian. They were used to emphasize the speaker's belief in the truth or factualness of the proposition expressed by the clause, contrasting it with its implicit negation.

From the beginning, my aim was to write a study that is accessible to both linguists and sumerologists. Modern descriptive linguistic works refer to Sumerian only rarely, and if they do, then their authors often misunderstand the descriptions. The main reason for this state of affairs is that studies on Sumerian written by sumerologists typically use idiosyncratic terminology and hardly ever gloss their examples (an important exception is Jagersma 2010). The unique writing system used to record the language presents another obstacle for the linguist not trained as an assyriologist.

This is to be regretted, for the present work has shown that Sumerian has a number of unique and interesting characteristics that may add to our knowledge about patterns of linguistic variation across languages. The attributive copular biclausal construction discussed in Chapter 4 provides an interesting and well-documented example of an otherwise only scarcely attested relativization strategy. No 
typological work on relative clauses may now be considered comprehensive without taking into account Sumerian paratactic relative clauses. The specificational copular biclausal construction described in Chapter 5 provides the oldest known and documented example of the path of grammaticalization that leads from a copula to a focus marker. The thetic construction discussed in Chapter 6 adds a brand new type to the range of constructions used to express sentence focus in the languages of the world, as described by Lambrecht (2000).

I also hope that this work may set a precedent for future studies on Sumerian grammar. It may demonstrate that using the terminology and findings of modern descriptive linguistics potentially results not only in describing something wellknown in a more complicated and less comprehensible way, as assumed tacitly by some in my field, but can also further our understanding the Sumerian language and the texts which are written in it in substantially greater depth. 